Research Article

\title{
Effect of Slope Aspect and Land Use Types on Selected Soil Physicochemical Properties in North Western Ethiopian Highlands
}

\author{
Gebretsadik Melak Tamene $\mathbb{D}^{1},{ }^{1}$ Hailu Kindie Adiss, ${ }^{2}$ and Melese Yigzaw Alemu ${ }^{1}$ \\ ${ }^{1}$ Department of Natural Resource Management Collage of Agriculture and Environmental Science, University of Gondar, \\ Gondar, Ethiopia \\ ${ }^{2}$ Amhara Regional Agricultural Research Institute, Department of Soil and Water Management,, Bahir Dar, Ethiopia \\ Correspondence should be addressed to Gebretsadik Melak Tamene; gebretsadkmelak@gmail.com
}

Received 10 July 2019; Revised 26 February 2020; Accepted 28 February 2020; Published 17 August 2020

Academic Editor: Keith Smettem

Copyright (c) 2020 Gebretsadik Melak Tamene et al. This is an open access article distributed under the Creative Commons Attribution License, which permits unrestricted use, distribution, and reproduction in any medium, provided the original work is properly cited.

\begin{abstract}
Recent research findings imply that the slope aspect has a great impact on soil genesis and soil microclimate. The microclimate has a significant effect on the soil geobiochemical processes taking place in the soil. However, the slope aspect impact on soil properties has not been yet studied well in Ethiopia, particularly in the northern highlands. This research was initiated to link selected soil physicochemical properties with slope aspects under different land use practices. The research was conducted in GumaraMaksegnit watershed located at the upper Lake Tana basin, Ethiopia. Four slope aspects, eastward (Ew), northward (Nw), southward $(\mathrm{Sw})$, and westward $(\mathrm{Ww})$, and three land use types at each slope aspect, cropland $(\mathrm{Cl})$, forest land (Fl), and grazing land (Gl), were considered. In total, 36 undisturbed soil samples for bulk density and 36 disturbed soil samples for selected soil properties were collected. Soil particle size (texture), bulk density, electrical conductivity (EC), soil pH, available phosphorus (av. $\mathrm{P}$ ), available potassium (av. K), total nitrogen (TN), and soil organic carbon (SOC) were analyzed. The resulting analyses showed no significant variation $(p<0.05)$ across both slope aspects and/or land use types for soil $\mathrm{pH}$ and EC, whereas the slope aspect showed a significant effect $(p<0.05)$ on SOC, TN, av. K, and av. P. The highest significant $(p<0.05)$ mean value of SOC was observed in the $\mathrm{Ww}(3.04 \%)$ followed by $\mathrm{Nw}(2.52 \%)$ but SOC was not significant $(p<0.05)$ between Sw and Ew. While the highest av. K (1233.2 centimole/kilogram) and av. phosphorus $(35.76 \mathrm{ppm})$ were observed in Nw slope aspect, the highest TN was in the $W w$ slope aspect $(0.24 \%)$. The significant effect $(p<0.05)$ of land uses can be summarized as $\mathrm{Fl}>\mathrm{Gl}>\mathrm{Cl}$ for SOC and TN. A strong positive correlation was observed between SOC and TN $\left(R^{2}=0.997\right)$ and av. K and av. $\mathrm{P}\left(R^{2}=0.58\right)$ at $p<0.05$. Generally, the slope aspect, land use types, and their interaction had a significant effect on soil physicochemical properties.
\end{abstract}

\section{Introduction}

Ethiopian highland areas are characterized by high rainfall and have continually practiced diversified cultivation with rapid land use changes [1]. Improper agricultural practices such as overgrazing, continuous tillage, poor soil, and water conservation practices and soil acidity affect the soil ecology and properties [2]. Rapid land use land cover change (LULCC), poor land and soil management practices, conventional cropping system, and other agricultural activities are the most important driving forces of land degradation and soil fertility declination in Ethiopia [3]. Besides the mountainous topography, the slope gradient combined with traditional agriculture has aggravated soil fertility depletion, soil acidity, and soil organic matter depilation [4].

Recent research findings implied the slope aspect has also a great impact on soil genesis, soil microbial function and diversity, biomass production and soil organic matter, soil hydrology, and microclimate regulation. These factors affect the soil physicochemical properties $[5,6]$. The slope 
aspect can influence surface runoff and erosion due to the microclimate effect. Deviations due to topographic aspects brought diverse microclimates, causing differences in faunal abundance and diversity, soil moisture, temperature, and organic matter to affect soil fertility and ultimately soil quality [6]. Hydrological and solar energy systems of mountainous landscapes vary according to slope aspect, which leads to the variance in composition and distribution patterns of vegetation and soil biological properties [7].

Much research has been done on the effect of slope gradient and length; however the impact of slope aspect on soil geobiochemical processed research is still too limited in Ethiopia. This research was initiated to analyze the effect of slope aspect on selected soil physicochemical properties across different land use practices.

\section{Research Methodology}

2.1. Area Description. Gumara-Maksegnit watershed lies in the critical part of the Lake Tana basin which is the largest lake in Ethiopia under Megechi Catchment. This catchment drains into the Gumara-Maksegnit River, which ultimately drifts to Lake Tana (Figure 1). The biophysical processes in this catchment have a direct impact on the ecosystem of the Lake Tana. The Gumara-Maksegnit watershed is found in north Gondar zone of Gondar Zuria district with the geographical location which ranges between $12^{\circ} 23^{\prime} 53^{\prime \prime}$ to $12^{\circ} 30^{\prime} 49^{\prime \prime} \mathrm{N}$ and $37^{\circ} 33^{\prime} 39^{\prime \prime}$ to $37^{\circ} 37^{\prime} 14^{\prime \prime} \mathrm{E}$. The watershed is located approximately $45 \mathrm{~km}$ southwest of Gondar town. The altitude of the survey area ranges from $1933 \mathrm{~m}$ to $2852 \mathrm{~m}$ above sea level. The topography of the area covers from a gentle slope to a very steep slope.

2.2. Soil Sampling Design and Soil Sample Collection. Soil samples were collected from three land use types (cropland, grazing land, and natural forest) within four slope aspects, eastward (Ew), northward $(\mathrm{Nw})$, southward $(\mathrm{Sw})$, and westward (Ww), using GPS within three-meter accuracy. From each land use, the types of representative soil samples with three replications were taken by a simple random sampling technique from the upper $20 \mathrm{~cm}$ of topsoil. Elevation, slope gradient, and management practices have been made as homogeneous as possible, and similar land uses within the four slope aspects were used during sample collection. In total, 36 undisturbed and 36 disturbed soil samples were taken from the four slope aspects and the three land use types.

2.3. Soil Laboratory Analysis. Soil texture, bulk density, electrical conductivity (EC), soil $\mathrm{pH}$, available phosphorus (av. P), available potassium (av. K), total nitrogen (TN), and soil organic carbon (SOC) were analyzed. Soil texture was analyzed by the hydrometer method [8]. The 36 undisturbed soil samples were used to determine the bulk density (BD) [9] while the disturbed soil samples were used to determine other physical and chemical soil properties. Soil $\mathrm{pH}$ was measured using soil water: solution method at the ratio of 1 : 2.5 for soil: water solutions using a combined glass electrode
$\mathrm{pH}$ meter [10]. For the determination of soil OM, wet oxidation titrated with $0.25 \mathrm{M}$ ferrous sulfate solutions was used [11]. TN content was determined with the titration method following the Kjeldahl method as described by Jackson [12]. Av. K was measured by a flame photometer [13]. Available P was determined using the Olsen extraction method [14].

\subsection{Statistical Analysis. Two-way ANOVA with Duncans'} multiple range test was employed to test the mean separation between land uses types, slope aspects, and the interaction effect. The Pearson correlation coefficient was employed to determine the relationship between soil properties. All the inferential statistics were conducted using statistical analysis software (SAS).

\section{Results and Discussions}

3.1. Descriptive Analysis of Selected Soil Properties. The descriptive analyses of the results revealed that there was a numerical difference among the selected physicochemical soil properties across the slope aspect and land use types, while soil organic carbon and bulk density showed similar patterns (Figure 2). Eastward and northward slope aspects showed lower clay percentage numerically (Figure 3 ) which might be as a result of surface runoff, microclimate, and soil management variation [7]. Soil chemical properties are highly influenced by geobiochemical processes including topography, slope aspect, and slope gradient; soil fauna, vegetation, and hydrologic process; and climatic factors such as temperature and rainfall. For example, surface runoff and downward leaching could affect soil nutrient content, soil $\mathrm{pH}$, soil organic matter, soil respiration, and other soil biological characters. Table 1 confirms the effect of the slope aspect and land use types on selected soil properties.

\subsubsection{Effect of Slope Aspect and Land Use Types on Soil} Texture, Soil Bulk Density, and Soil Reaction. The significant difference in soil particle size distribution was observed between slope aspects. Eastward and northward slope aspects showed greater sand and silt contents while greater clay content was observed in the westward slope aspect (Table 2). Måren et al. [15] have reported the northward slope aspect has significantly more sand and silt content than the south face slope aspect but clay content was insignificant. In contrast, Bayat et al.'s [16] finding revealed that the north-facing slope has more clay and lower sand content than the south-facing slope. Such difference is due to the cumulative effect of microclimate and soil management variation including vegetation [7]. The difference in soil texture among the slope aspects has a great effect on soil biochemical processes such as mineralization and stabilization of soil organic matter [17]. There was no significant variation for soil $\mathrm{pH}$ and soil EC across slope aspects and land use types (Table 3 ). Regarding the bulk density lower bulk density was observed in $\mathrm{Ww}$ slope; hence, the westward watershed was 


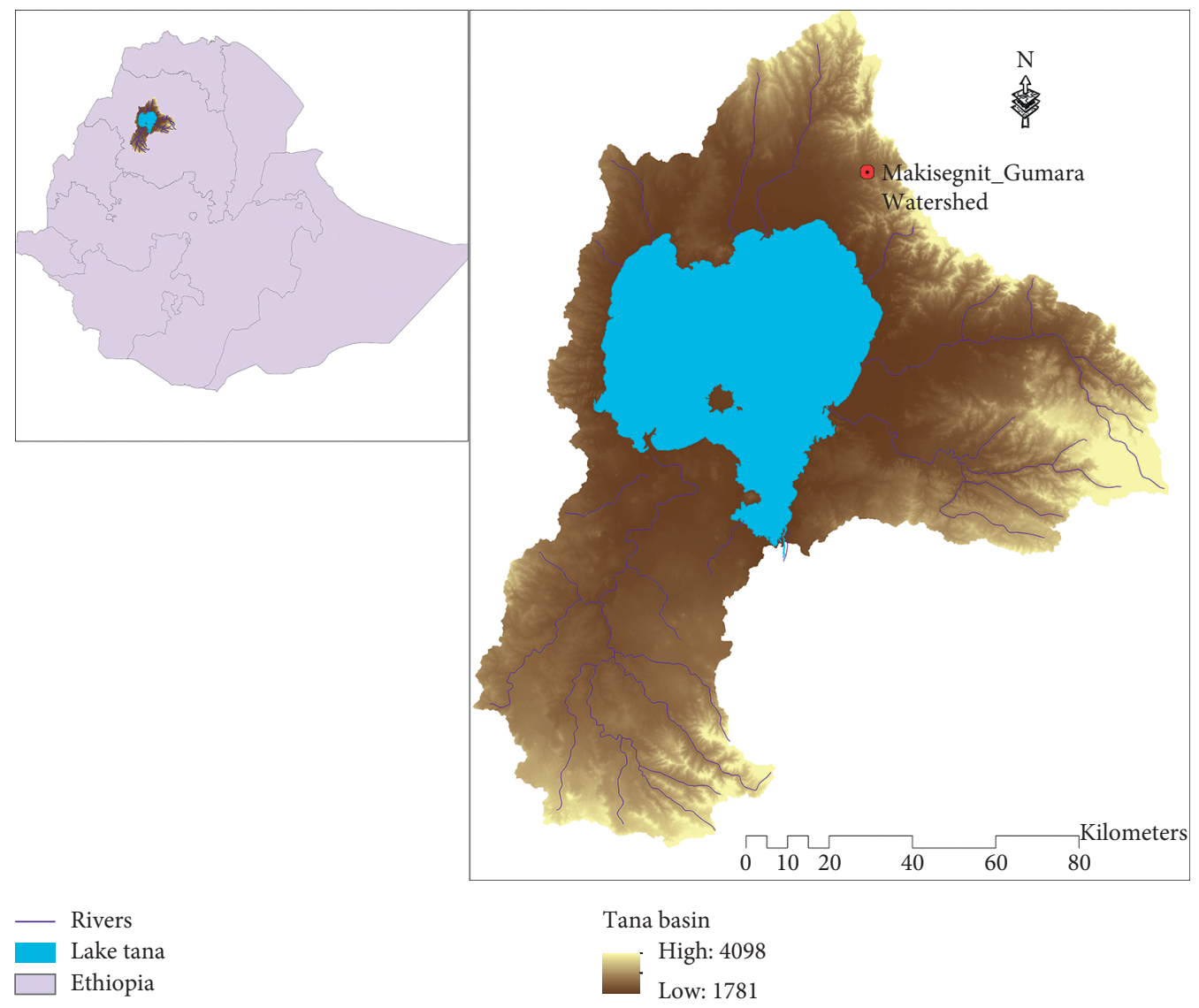

Figure 1: Study area map of Gumara-Maksegnit Watershed (WS).

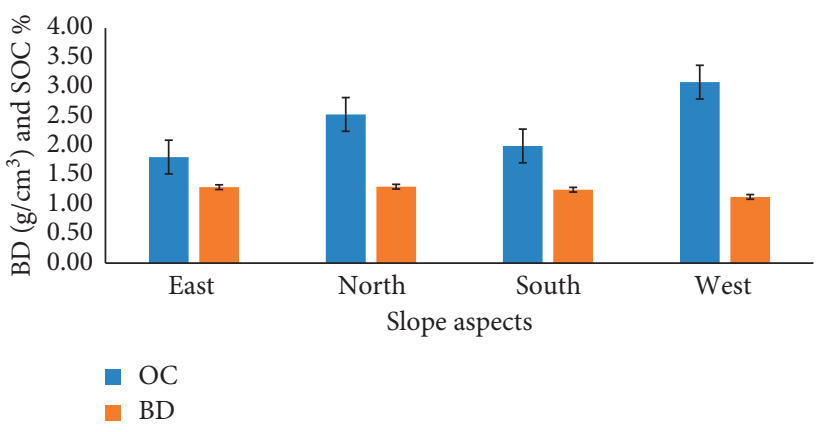

FIGURE 2: Bulk density and SOC across slope aspects (BD: bulk density in gram per centimeter cubic; OC: soil organic carbon in percent).

treated by soil and water conservation practices. This difference also could be associated with the variability of soil particle size distribution and SOC content among the slope aspects [6]. However, there was no significant variation with soil bulk density between $\mathrm{Ww}$ and Sw slop aspects (Table 4 ).

Forest land showed the greatest sand percentage, lowest clay percentage, and lowest bulk density. The reverse trend was observed in cropland (Table 2). Selassie et al. [18] reported higher clay percentage in a natural forest than both cropland and grazing land in contrast to this research finding. Meanwhile, Tufa et al. [19] documented that land use types do not have a significant effect on soil particle size distribution. The insignificant difference of soil particle sizes distribution between virgin forest soil and farming land was also reported in Morocco [20]. Higher bulk density in croplands might be due to lower soil organic matter content [21].

3.1.2. Primary Essential Nutrients and SOC across Slope Aspect and Land Use Types. Essential nutrient status is very important for analysis of the suitability of lands for agricultural productivity. Both land uses and slope aspects showed a significant effect on the primary macroessential nutrients even though the difference is not consistent (Table 3). A greater SOC was observed in $\mathrm{Ww}$ and $\mathrm{NW}$ slope aspects while the lowest was observed in Ew and Sw slope aspects (Table 3 ) in line with [22]. The north-facing sites are usually cool and moist and contain higher amounts of SOC, whereas south-facing slopes are usually hot and dry, with less vegetation, prone to erosion, and hence depleted in SOC [6]. Yuan et al. [21] also reported that the north- and southwest aspects of the watershed had a higher fraction of SOC than other aspects.

The lowest SOC and TN were observed under cropland use type (Table 3) which might be due to the fast mineralization of soil organic matter and greater erosion than forest and grazing land [23]. The soil organic matter physical protection (stabilization) in conventionally 


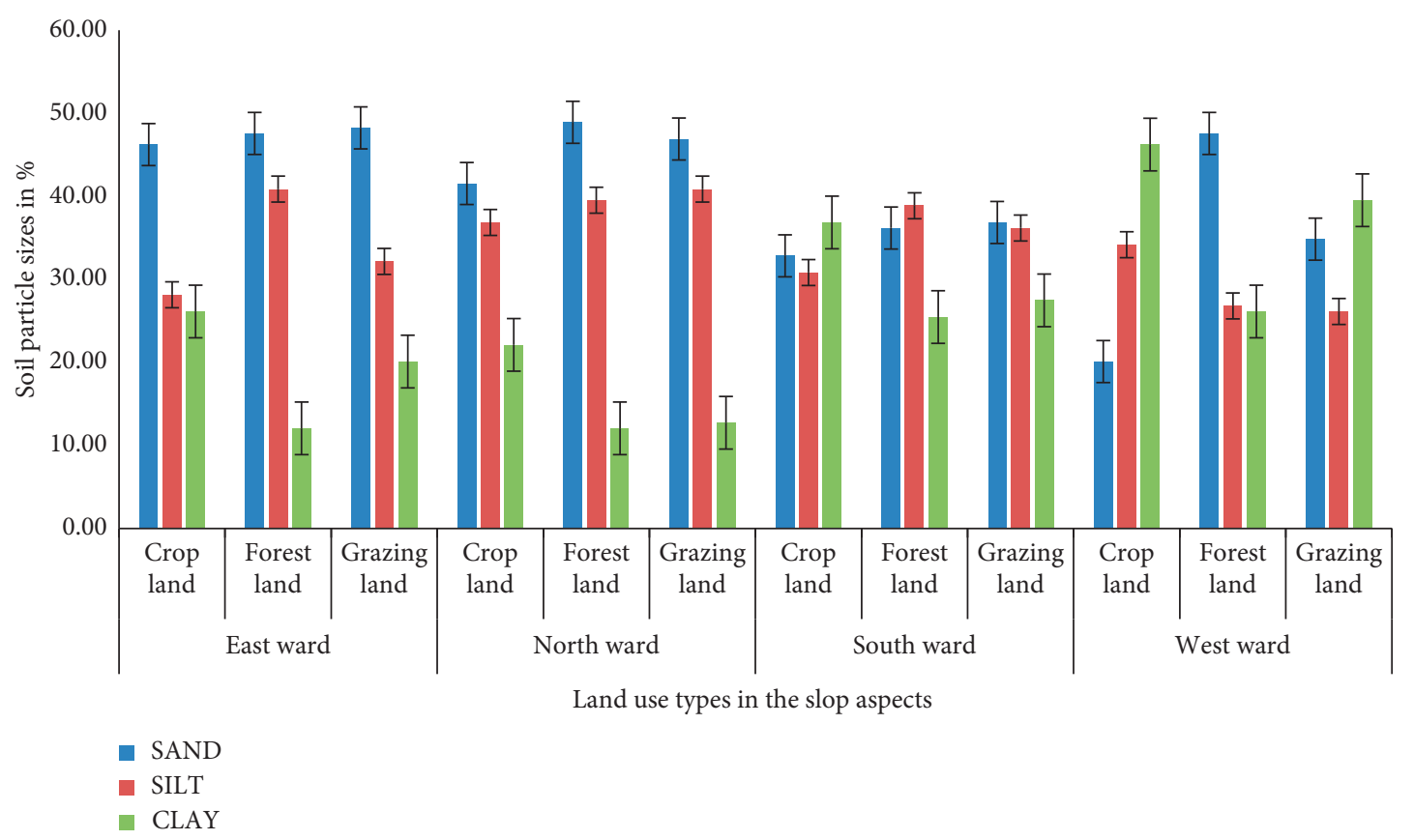

FIgURE 3: Particle size distribution among slope aspect and land use types.

TABle 1: Descriptive statistics of selected soil properties across slope aspects and land use types.

\begin{tabular}{|c|c|c|c|c|c|c|c|c|c|c|c|c|c|}
\hline \multirow{2}{*}{$\mathrm{Lu}$} & \multirow{2}{*}{ Var. } & \multicolumn{3}{|c|}{ Ew } & \multicolumn{3}{|c|}{$\mathrm{Nw}$} & \multicolumn{3}{|c|}{ Sw } & \multicolumn{3}{|c|}{ Ww } \\
\hline & & Mean & Min & Max & Mean & Min & Max & Mean & Min & Max & Mean & Mini & Max \\
\hline \multirow{6}{*}{$\mathrm{CL}$} & $\mathrm{pH}$ & 6.64 & 6.43 & 6.99 & 7.04 & 6.78 & 7.42 & 7.02 & 6.93 & 7.17 & 6.92 & 6.88 & 6.96 \\
\hline & EC & 0.08 & 0.03 & 0.12 & 0.09 & 0.05 & 0.17 & 0.04 & 0.03 & 0.05 & 0.04 & 0.03 & 0.05 \\
\hline & Av. K & 343.33 & 115.2 & 468.50 & 1116.8 & 677.50 & 1572.5 & 186.9 & 105.8 & 282.5 & 1319.6 & 857.5 & 1642.5 \\
\hline & SOC & 1.11 & 0.90 & 1.21 & 1.35 & 1.13 & 1.56 & 1.25 & 0.98 & 1.40 & 2.40 & 1.83 & 2.69 \\
\hline & $\mathrm{TN}$ & 0.08 & 0.07 & 0.09 & 0.11 & 0.09 & 0.12 & 0.10 & 0.08 & 0.11 & 0.19 & 0.14 & 0.21 \\
\hline & Av. P & 25.67 & 6.90 & 41.30 & 59.63 & 58.80 & 61.30 & 12.27 & 0.30 & 30.00 & 35.63 & 15.60 & 52.50 \\
\hline \multirow{6}{*}{$\mathrm{FL}$} & $\mathrm{pH}$ & 6.67 & 6.60 & 6.78 & 6.93 & 6.68 & 7.23 & 6.76 & 6.67 & 6.82 & 6.23 & 5.10 & 6.92 \\
\hline & EC & 0.09 & 0.06 & 0.13 & 0.07 & 0.05 & 0.10 & 0.08 & 0.05 & 0.13 & 0.03 & 0.01 & 0.08 \\
\hline & Av. K & 1307.7 & 945.3 & 1850.50 & 1105.8 & 1032.5 & 1187.5 & 215.5 & 128.5 & 355.0 & 541.9 & 165.9 & 1017.5 \\
\hline & SOC & 2.77 & 2.54 & 2.93 & 3.05 & 2.61 & 3.78 & 3.08 & 2.07 & 4.41 & 4.22 & 3.90 & 4.52 \\
\hline & $\mathrm{TN}$ & 0.22 & 0.20 & 0.23 & 0.23 & 0.20 & 0.29 & 0.24 & 0.16 & 0.34 & 0.33 & 0.30 & 0.35 \\
\hline & Av. P & 52.53 & 43.80 & 60.00 & 25.87 & 13.80 & 47.50 & 15.00 & 2.30 & 33.80 & 5.70 & 1.40 & 11.40 \\
\hline \multirow{6}{*}{ GL } & $\mathrm{pH}$ & 6.82 & 6.68 & 6.89 & 6.78 & 6.73 & 6.85 & 7.02 & 6.96 & 7.06 & 6.13 & 5.46 & 6.50 \\
\hline & EC & 0.05 & 0.03 & 0.08 & 0.05 & 0.05 & 0.06 & 0.05 & 0.04 & 0.06 & 0.04 & 0.04 & 0.05 \\
\hline & Av. K & 517.1 & 416.2 & 578.8 & 1476.8 & 1175.5 & 1757.5 & 107.5 & 78.9 & 130.0 & 675.8 & 317.5 & 1190.0 \\
\hline & SOC & 1.52 & 1.17 & 1.95 & 2.50 & 2.93 & 3.32 & 1.63 & 0.98 & 2.15 & 2.59 & 2.18 & 2.93 \\
\hline & $\mathrm{TN}$ & 0.12 & 0.09 & 0.15 & 0.25 & 0.23 & 0.26 & 0.13 & 0.08 & 0.17 & 0.19 & 0.14 & 0.23 \\
\hline & Av. P & 14.40 & 10.30 & 20.60 & 21.77 & 5.10 & 49.40 & 3.57 & 1.40 & 5.50 & 6.51 & 2.63 & 12.50 \\
\hline
\end{tabular}

Lu: land use types; Var: variables; EC: electrical conductivity; SOC: in percent; Av. K: in centimole/kilogram, Av. P: by ppm; TN: in percent; Ew: eastward; Nw: northward; Sw: southward; Ww: westward; Fl: forest land; Cl: cropland; Gl: grazing land.

tilled land is lower since the soil is more frequently disturbed than forest and grazing lands [24]. Tinker et al. [25] have also reported the factors contributing to the net decline of SOC during cultivation: erosion on sloping lands, lower litter inputs, and increased SOM oxidation caused by tillage as cited by Nandwa [26]. The effect of land use types on av. K was nonsignificant (Table 3). Av. P was the lowest in grazing land and was nonsignificant between cropland and forest lands. Application of DAP fertilizer in cropland might increase the av. P in croplands [27] while the mineralized phosphorus from organic matter might be the main reason for higher av. $\mathrm{P}$ in forest land [28].

The interaction effect of slope aspect and land use types was significant regarding soil $\mathrm{pH}, \mathrm{SOC}$, av. $\mathrm{K}$, av. P, and TN (Table 4). Ww grazing land and forest land showed the 
TABLE 2: Main effect of slope aspect and land use types on selected soil properties.

\begin{tabular}{|c|c|c|c|c|c|c|}
\hline $\begin{array}{l}\text { Treatment } \\
(\mathrm{DF}=30)\end{array}$ & Sand (\%) & Silt (\%) & Clay (\%) & $\mathrm{BD}\left(\mathrm{g} / \mathrm{cm}^{3}\right)$ & $\mathrm{pH}$ & $\mathrm{EC}(\mathrm{dS} / \mathrm{m})$ \\
\hline Ew & $47.1 \pm 1.7 \mathrm{a}$ & $33.56+2.2 \mathrm{ba}$ & $19.33 \pm 3.1 \mathrm{c}$ & $1.29 \pm 0.05 a$ & $6.71 \pm 0.08$ & $0.07 \pm 0.03$ \\
\hline $\mathrm{Nw}$ & $45.56 \pm 2.1 \mathrm{a}$ & $38.89 \pm 1.5 \mathrm{a}$ & $15.56 \pm 1.2 \mathrm{c}$ & $1.30 \pm 0.05 a$ & $6.92 \pm 0.06$ & $0.07 \pm 0.03$ \\
\hline Sw & $35.11 \pm 1.5 b$ & $35.11 \pm 1.8 \mathrm{c}$ & $29.78 \pm 3.3 b$ & $1.25 \pm 0.03 \mathrm{ba}$ & $6.93 \pm 0.05$ & $0.05 \pm 0.02$ \\
\hline Ww & $34.00 \pm 5.0 \mathrm{~b}$ & $28.89 \pm 2.1 \mathrm{c}$ & $37.11 \pm 3.7 \mathrm{a}$ & $1.12 \pm 0.06 b$ & $6.42 \pm 0.22$ & $0.04 \pm 0.02$ \\
\hline $\begin{array}{l}\text { Sign. } \\
(0.05)\end{array}$ & $*$ & $*$ & $*$ & $*$ & Ns & Ns \\
\hline $\mathrm{Cl}$ & $35.00 \pm 3.3 \mathrm{~b}$ & $32.33 \pm 1.5$ & $32.68 \pm 3.7 \mathrm{a}$ & $1.28 \pm 0.04 \mathrm{a}$ & $6.90 \pm 0.08$ & $0.063 \pm 0.01$ \\
\hline $\mathrm{Fl}$ & $44.83 \pm 2.7 \mathrm{a}$ & $36.33 \pm 2.2$ & $18.83 \pm 2.5 \mathrm{c}$ & $1.13 \pm 0.04 \mathrm{~b}$ & $6.65 \pm 015$ & $0.069 \pm 0.01$ \\
\hline Gl & $41.5 \pm 2.7 \mathrm{a}$ & $33.68 \pm 2.0$ & $24.83 \pm 3.4 b$ & $1.30 \pm 0.4 \mathrm{a}$ & $6.69 \pm 0.12$ & $0.048 \pm 0.00$ \\
\hline $\begin{array}{l}\text { Sign. } \\
(0.05)\end{array}$ & $*$ & Ns & $*$ & $*$ & Ns & Ns \\
\hline
\end{tabular}

DF: degree of freedom; BD: bulk density; EC: electrical conductivity; Ew: eastward; Nw: northward; Sw: southward; sign: significant; Fl: forest land; Cl: cropland; Gl: grazing land. The numbers indicated by \pm are standard errors.

TABLE 3: The main effect of slope aspect and land use types on SOC and primary macroessential nutrients.

\begin{tabular}{|c|c|c|c|c|}
\hline Treatment $(\mathrm{DF}=30)$ & SOC (\%) & Av. K (cmole/kg) & Av. P (ppm) & $\mathrm{TN}(\%)$ \\
\hline Ew & $1.80 \pm 0.3 c$ & $722.7 \pm 172 b$ & $30.87 \pm 6.6 \mathrm{a}$ & $0.14 \pm 0.02 \mathrm{c}$ \\
\hline $\mathrm{Nw}$ & $2.52 \pm 0.3 b$ & $1233.2 \pm 108 \mathrm{a}$ & $35.76 \pm 7.9 a$ & $0.20 \pm 0.02 b$ \\
\hline Sw & $1.99 \pm 0.3 c$ & $172 \pm 30 c$ & $10.28 \pm 4.2 b$ & $0.16 \pm 0.03 c$ \\
\hline Ww & $3.04 \pm 03 \mathrm{a}$ & $845.8 \pm 172 b$ & $15.95 \pm 6.0 \mathrm{~b}$ & $0.24 \pm 0.02 \mathrm{a}$ \\
\hline Sign. (0.05) & $*$ & $*$ & $*$ & * \\
\hline $\mathrm{CL}$ & $1.53 \pm 0.17 \mathrm{c}$ & $741.7 \pm 166$ & $33.30 \pm 6.4 \mathrm{a}$ & $0.112 \pm 0.01 \mathrm{c}$ \\
\hline FL & $3.28 \pm 0.24 \mathrm{a}$ & $792.8 \pm 154$ & $24.78 \pm 6.2 \mathrm{a}$ & $0.253 \pm 0.02 a$ \\
\hline GL & $2.23 \pm 0.23 b$ & $694.3 \pm 164$ & $11.56 \pm 6.8 b$ & $0.172 \pm 0.02 b$ \\
\hline Sign. (0.05) & $*$ & Ns & $*$ & $*$ \\
\hline
\end{tabular}

DF: degree of freedom; SOC: in percent; Av. K: in centimole/kilogram; Av. P: by ppm; TN: TN in percent, Ew: eastward; Nw: northward; Sw: southward; Ww: westward; sign: significant; Fl: forest land; Cl: cropland; Gl: grazing land. The numbers indicated by \pm are standard errors.

TABLE 4: Interaction effect of slope aspect and LU on SOC and primary macroessential nutrients.

\begin{tabular}{|c|c|c|c|c|c|}
\hline Treatment $(\mathrm{DF}=24)$ & $\mathrm{Ph}$ & SOC (\%) & Av. K (cmole/kg) & Av. P (ppm) & $\mathrm{TN}(\%)$ \\
\hline $\mathrm{Ew} * \mathrm{Cl}$ & $6.64 \pm 0.18 \mathrm{cba}$ & $1.11 \pm 0.17 \mathrm{~d}$ & $343.3 \pm 91 c$ & $25.67 \pm 3.5 b c$ & $0.08 \pm 0.01 \mathrm{e}$ \\
\hline $\mathrm{Ew} * \mathrm{Fl}$ & $6.67 \pm 0.06 \mathrm{cba}$ & $2.77 \pm 0.11 \mathrm{a}$ & $1307 \pm 276.8 \mathrm{a}$ & $52.53 \pm 4.7 \mathrm{a}$ & $0.22 \pm 0.01 b$ \\
\hline EwvGl & $6.82 \pm 0.07 \mathrm{cba}$ & $1.52 \pm 0.23 \mathrm{~cd}$ & $517.1 \pm 50 c$ & $14.4 \pm 3.2 \mathrm{bc}$ & $0.12 \pm 0.02 \mathrm{ed}$ \\
\hline $\mathrm{Nw} * \mathrm{Cl}$ & $7.04 \pm 0.19 a$ & $1.35 \pm 0.12 \mathrm{~d}$ & $1116.8 \pm 258 \mathrm{ba}$ & $59.63 \pm 0.83 a$ & $0.11 \pm 0.01 \mathrm{e}$ \\
\hline $\mathrm{Nw} * \mathrm{Fl}$ & $6.93 \pm 0.16 \mathrm{cba}$ & $3.05 \pm 0.37 \mathrm{a}$ & $1105.8 \pm 45 \mathrm{ba}$ & $25.87 \pm 10.8 b c$ & $0.23 \pm 0.03 b$ \\
\hline $\mathrm{Nw} * \mathrm{Gl}$ & $6.78 \pm 0.04 \mathrm{ba}$ & $2.50 \pm 0.12 \mathrm{~d}$ & $1476.8 \pm 168 \mathrm{a}$ & $21.77 \pm 13.9 b c$ & $0.25 \pm 0.01 b$ \\
\hline $\mathrm{Sw} * \mathrm{Cl}$ & $7.02 \pm 0.08 \mathrm{a}$ & $1.25 \pm 0.14 \mathrm{a}$ & $186.9 \pm 52 c$ & $12.27 \pm 9.0 \mathrm{bc}$ & $0.1 \pm 0.01 \mathrm{e}$ \\
\hline $\mathrm{Sw} * \mathrm{Fl}$ & $6.76 \pm 0.05 \mathrm{cba}$ & $3.08 \pm 0.69 a$ & $215.5 \pm 70 c$ & $15 \pm 9.6 b c$ & $0.24 \pm 0.05 b$ \\
\hline $\mathrm{Sw} * \mathrm{Gl}$ & $7.02 \pm 0.03 a$ & $1.63 \pm 0.14 \mathrm{~cd}$ & $107.6 \pm 15 c$ & $3.57 \pm 1.2 \mathrm{c}$ & $0.13 \pm 0.03 \mathrm{ced}$ \\
\hline $\mathrm{Ww} * \mathrm{Cl}$ & $6.92 \pm 0.03 \mathrm{ba}$ & $2.40 \pm 0.29 \mathrm{cb}$ & $1319.7 \pm 237 a$ & $35.63 \pm 10.8 \mathrm{ba}$ & $0.19 \pm 0.01 \mathrm{cbd}$ \\
\hline $\mathrm{Ww} * \mathrm{Fl}$ & $6.23 \pm 0.06 b c$ & $4.22 \pm 0.18 \mathrm{a}$ & $542 c \pm 251 b c$ & $5.7 \pm 3.0 \mathrm{c}$ & $0.33 \pm 0.01 b$ \\
\hline $\mathrm{Ww} * \mathrm{Gl}$ & $6.13 \pm 0.34 c$ & $2.59 \pm 0.22 b$ & $675.8 \pm 261 b c$ & $6.51 \pm 3.0 \mathrm{c}$ & $0.19 \pm 0.03 \mathrm{cb}$ \\
\hline Sign. $(0.05 \%)$ & $*$ & $*$ & $*$ & $*$ & $*$ \\
\hline
\end{tabular}

DF: degree of freedom; SOC: in percent; Av. K: in centimole/kilogram; Av. P: by ppm; TN: in percent, Ew: eastward; Nw: northward; Sw: southward; Ww: westward; sign: significant; Fl: forest land; Cl: cropland; Gl: grazing land. The numbers indicated by \pm are standard errors.

lowest soil $\mathrm{pH}$ while Sw cropland and grazing lands showed the highest $\mathrm{pH}$ (Table 4).

3.2. Correlation between Soil Properties Measured. The person correlation result showed that there was a strong positive significant correlation between SOC and TN $(r=0.997 ; p \leq 0.05$ (Table 5 and Figure 4). This finding is in line with the finding of Cao [29] which reported SOC and TN were positively correlated with $r=0.869$ at $p \leq 0.05$. This might be because the main source for both SOC and soil TN is soil organic matter. Cusack et al. [30] also reported a significant positive correlation between $\mathrm{C}$ and $\mathrm{N}$ concentrations in forest soils with $r=0.93$. A moderately positive correlation was observed between soil av. $\mathrm{K}$ and av. $\mathrm{P}$ (Figure 5) and between av. P and EC $(r=0.58$ and 0.52 , resp.) at $p=0.05$ (Figure 6). Bulk density showed weak negative correlation with both SOC and TN while a strong negative correlation was observed between clay and sand 
TABLE 5: Correlation between observed soil physicochemical properties.

\begin{tabular}{|c|c|c|c|c|c|c|c|c|c|c|}
\hline & $\mathrm{pH}$ & $\mathrm{EC}$ & Sand & Silt & Clay & Av. K & OC & Total. N & Av. P & $\mathrm{Bd}$ \\
\hline $\mathrm{pH}$ & 1 & $-0.069 \mathrm{~ns}$ & $-.21 \mathrm{~ns}$ & $0.42^{*}$ & $-0.05 \mathrm{~ns}$ & $0.12 \mathrm{~ns}$ & $-0.41^{*}$ & $-0.41^{*}$ & $0.15 \mathrm{~ns}$ & $0.23 \mathrm{~ns}$ \\
\hline $\mathrm{EC}$ & & 1 & $0.23 \mathrm{~ns}$ & $0.23 \mathrm{~ns}$ & $-0.32 \mathrm{~ns}$ & $0.19 \mathrm{~ns}$ & 0.03 & $0.03 \mathrm{~ns}$ & $0.52^{*}$ & $0.05 \mathrm{~ns}$ \\
\hline Sand & & & 1 & $-0.05 \mathrm{~ns}$ & $-0.84^{*}$ & $0.14 \mathrm{~ns} 1$ & $0.19 \mathrm{~ns}$ & $0.20 \mathrm{~ns}$ & $0.15 \mathrm{~ns}$ & $-0.002 \mathrm{~ns}$ \\
\hline Silt & & & & 1 & $-0.50^{*}$ & $0.29 \mathrm{~ns}$ & $0.06 \mathrm{~ns}$ & $0.06 \mathrm{~ns}$ & $0.27 \mathrm{~ns}$ & $0.30 \mathrm{~ns}$ \\
\hline Clay & & & & & 1 & $-0.28 \mathrm{~ns}$ & $-0.20 \mathrm{~ns}$ & $-0.21 \mathrm{~ns}$ & $-0.28 \mathrm{~ns}$ & $-0.16 \mathrm{~ns}$ \\
\hline Av. K & & & & & & 1 & $0.24 \mathrm{~ns}$ & $0.25 \mathrm{~ns}$ & $0.58 * *$ & $0.13 \mathrm{~ns}$ \\
\hline $\mathrm{OC}$ & & & & & & & 1 & $0.997^{*}$ & $-0.03 \mathrm{~ns}$ & $-0.38^{*}$ \\
\hline Total. N & & & & & & & & 1 & $-0.022 \mathrm{~ns}$ & $-0.38^{*}$ \\
\hline Av. P & & & & & & & & & 1 & $0.22 \mathrm{~ns}$ \\
\hline $\mathrm{Bd}$ & & & & & & & & & & 1 \\
\hline
\end{tabular}

Lu: land use types; Var: variables; DF: degree of freedom; BD: bulk density; EC: electrical conductivity; SOC: soil organic carbon; Av. K: available potassium; Av. P: available phosphorus; TN: total nitrogen; Ew: eastward; Nw: northward; Sw: southward; Ww: westward; sign: significant; Fl: forest land; Cl: cropland; Gl: grazing land. The numbers indicated by \pm are standard errors.

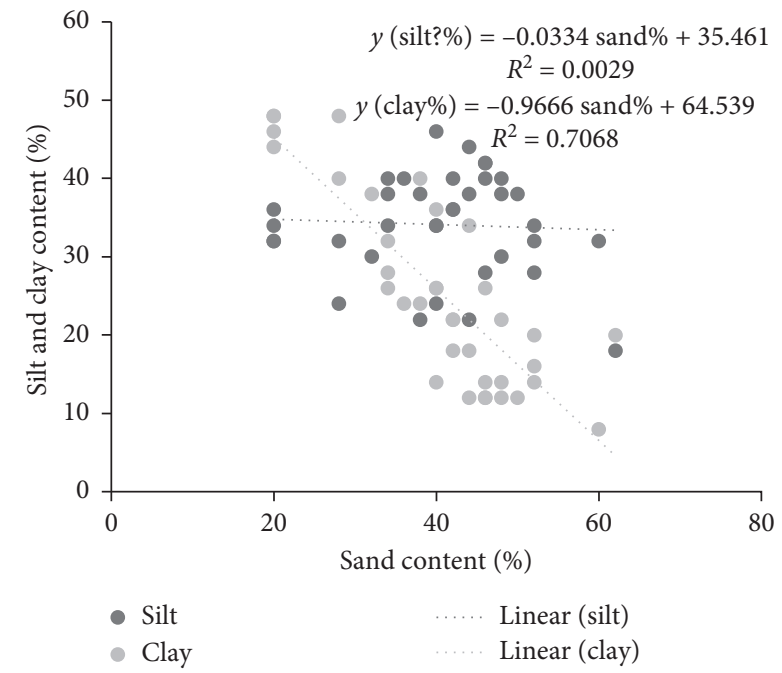

FIGURE 4: Linear regression between soil separates.

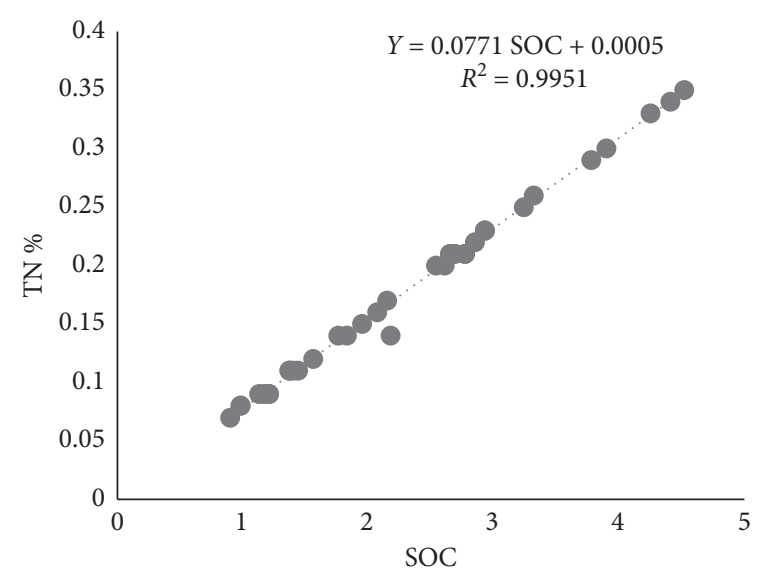

Figure 5: Linear regression between SOC and TN.

$(r=-0.84)$ and clay and silt percentage $(r=0.50)$ at $p \leq 0.05$ (Table 5). Soil $\mathrm{pH}$ was negatively correlated with SOC and TN (Table 5). The scatter plot revealed again the data normality is very accurate when compared to other measured soil parameters which confirm that the soil organic

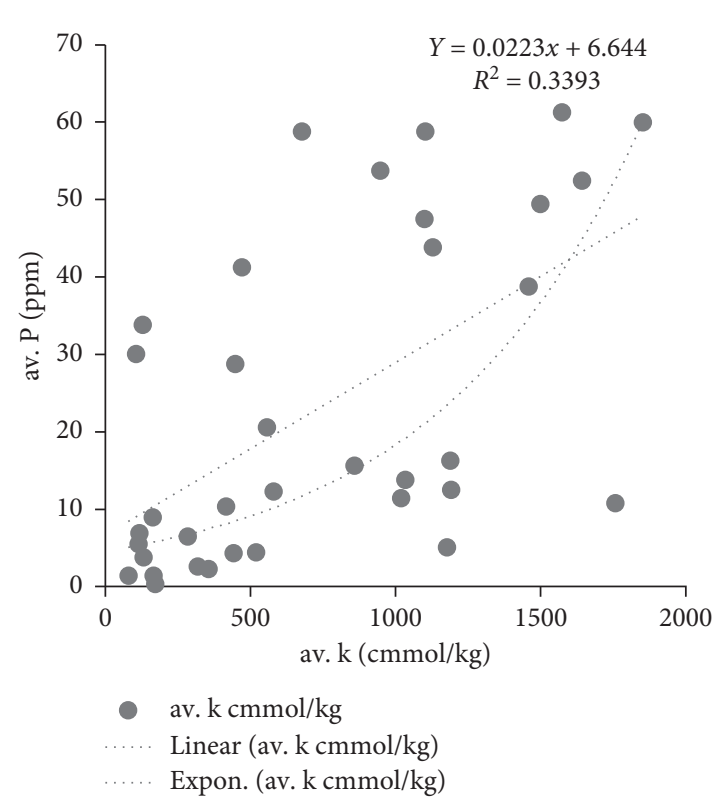

FIgURE 6: Linear regression of av. K versus av. P.

matter and total nitrogen significantly correlate (Figure 4) and is affected by the interaction effect of land use and slope aspect.

\section{Conclusion and Recommendations}

In this research, we have investigated the effect of the slope aspect in different land use types. Based on our findings, EC and $\mathrm{pH}$ did not response to both slope aspect and land use types. Significantly higher clay content (37.11\%) was observed in Ww slope croplands, which might be due to the cumulative effect of microclimate and long-term land management practices. The interaction effect of slope aspect and land use on SOC (4.22) and TN (0.33) was the highest in westward natural forest land while the lowest was observed in eastward cropland SOC (1.11) and TN (0.08), which is highly associated with the biochemical process depending on the microclimate condition. The highest av. K (1476.8 (centimole/kg)) and av. P (59.63 (ppm)) was found in Nw grazing land and Nw cropland while the lowest av. K (107.6 
(centimole/kg)) and av. P (3.57 (ppm)) was found at Sw grazing land. There was a strong positive correlation between SOC and TN ( $r=0.997)$, and av. K and av. P ( $r=0.58)$. Generally, the slope aspect, land use types, and their interaction had a significant effect on soil physicochemical properties. This might imply that the slope aspect and land use types need detailed characterization during soil surveys and management.

\section{Data Availability}

All raw and analyzed data are in the hands of the corresponding author and can be available based on the reasonable request of the publisher or any interested body.

\section{Consent}

The official letter was obtained and given to participants from the University of Gondar. All participants of the study fully agreed upon and were interested in the study.

\section{Conflicts of Interest}

The authors declare that they have no conflicts of interest.

\section{Authors' Contributions}

All the authors participated in every phase of this research. They all participated in proposal writing, data collection, analysis, and interpretation.

\section{Acknowledgments}

The authors acknowledge the University of Gondar, agricultural officers, and peasants living in the study area. This research is financially supported by the research and community service vice president research platform of the University of Gondar. The research proposal was evaluated and funded by the University of Gondar and agreed to disseminate the final result via publication.

\section{References}

[1] M. Mohammed, B. Bedadi, K. Kibret, and Y. Mulat, "Soil organic carbon stock under different land use types in Kersa Sub Watershed, Eastern Ethiopia," African Journal of Agricultural Research, vol. 13, no. 24, pp. 1248-1256, 2018.

[2] F. Yimer, S. Ledin, and A. Abdelkadir, "Soil property variations in relation to topographic aspect and vegetation community in the south-eastern highlands of Ethiopia," Forest Ecology and Management, vol. 232, no. 1-3, pp. 90-99, 2006.

[3] C. Gougoulias, J. M. Clark, and L. J. Shaw, "The role of soil microbes in the global carbon cycle: tracking the belowground microbial processing of plant-derived carbon for manipulating carbon dynamics in agricultural systems," Journal of the Science of Food and Agriculture, vol. 94, no. 12, pp. 2362-2371, 2014.

[4] A. Madalcho and M. Tefera, "Management of traditional agroforestry practices in gununo watershed in wolaita zone, Ethiopia," Forest Research, vol. 5, no. 163, p. 2, 2016.

[5] A. Akbari, R. Azimi, and N. Bin, "Influence of slope aspects and depth on soil properties in a Cultivated Ecosystem,"
Electronic Journal of Geotechnical Engineering, vol. 19, pp. 8601-8608, 2014.

[6] F. Begum, R. M. Bajracharya, S. Sharma, and B. K. Sitaula, "Influence of slope aspect on soil physico-chemical and biological properties in the mid hills of central Nepal," International Journal of Sustainable Development \& World Ecology, vol. 17, no. 5, pp. 438-443, 2010.

[7] F. Yimer, S. Ledin, and A. Abdelkadir, "Soil organic carbon and total nitrogen stocks as affected by topographic aspect and vegetation in the Bale Mountains, Ethiopia," Geoderma, vol. 135, pp. 335-344, 2006.

[8] A. N. Beretta, A. V. Silbermann, L. Paladino et al., "Soil texture analyses using a hydrometer: modification of the Bouyoucos method," Ciencia e investigación agraria, vol. 41, no. 2, pp. 25-26, 2014.

[9] S. Sahlemedhin and B. Taye, Procedure for Soil and Plant Analysis. National Soil Research Centre, Ethiopian Agricultural Research Organization, Addis Ababa, Ethiopia, 2000.

[10] S. Chopra and J. S. Kanwar, Analytical Agricultural Chemistry, Kalyani, New Delhi, India, 1976.

[11] A. Walkley and I. A. Black, "An examination of the Degtjareff method for determining soil organic matter, and a proposed modification of the chromic acid titration method," Soil Science, vol. 37, no. 1, pp. 29-38, 1934.

[12] M. L. Jackson, "Nitrogen determinations for soil and plant tissue," in Soil Chemical Analysis, pp. 183-204, Prentice-Hall, Trenton, NJ, USA, 1958.

[13] M. F. Morgan, Chemical Soil Diagnosis by the Universal Soil Testing System, Vol. 450, Forgotten Books, London, UK, 1941.

[14] S. R. Olsen, Estimation of Available Phosphorus in Soils by Extraction with Sodium Bicarbonate, US Department of Agriculture, Washington, DC, USA, 1954.

[15] I. E. Måren, S. Karki, C. Prajapati, R. K. Yadav, and B. B. Shrestha, "Facing north or south: does slope aspect impact forest stand characteristics and soil properties in a semiarid trans-Himalayan valley?" Journal of Arid Environments, vol. 121, pp. 112-123, 2015.

[16] H. Bayat, M. Sheklabadi, M. Moradhaseli, and E. Ebrahimi, "Effects of slope aspect, grazing, and sampling position on the soil penetration resistance curve," Geoderma, vol. 303, pp. 150-164, 2017.

[17] M. Sidari, G. Ronzello, G. Vecchio, and A. Muscolo, "Influence of slope aspects on soil chemical and biochemical properties in a Pinus laricio forest ecosystem of Aspromonte (Southern Italy)," European Journal of Soil Biology, vol. 44, no. 4, pp. 364-372, 2008.

[18] Y. G. Selassie, F. Anemut, and S. Addisu, "The effects of land use types, management practices and slope classes on selected soil physico-chemical properties in Zikre watershed, NorthWestern Ethiopia," Environmental Systems Research, vol. 4, no. 1, p. 3, 2015.

[19] M. Tufa, A. Melese, and W. Tena, "Effects of land use types on selected soil physical and chemical properties: the case of Kuyu District, Ethiopia," Eurasian Journal of Soil Science (EJSS), vol. 8, no. 2, pp. 94-109, 2019.

[20] V. A. Tellen and B. P. K. Yerima, "Effects of land use change on soil physicochemical properties in selected areas in the North West region of Cameroon," Environmental Systems Research, vol. 7, no. 1, p. 3, 2018.

[21] Y. Yuan, X. Shi, and Z. Zhao, "Land use types and geomorphic settings reflected in soil organic carbon distribution at the scale of watershed," Sustainability, vol. 10, no. 10, p. 3490, 2018. 
[22] M. Schmidt, "An evaluation of the resources and forest soil fertility of a mountain watershed in Nepal using GIS techniques," Soil Fertility and Erosion Issues in the Middle Mountains of Nepal, ISS/UBC/IDRC, Kathmandu, Nepal, 1991.

[23] L. W. Ng"ang"a, S. Letema, and D. M. A. Thuo, "Quantification of soil organic carbon stocks across different land use types, soil types and agro-ecological zones in murang'a county, Kenya," Journal of Agriculture and Veterinary Science, vol. 11 , no. 11 , pp. $48-54,2018$.

[24] M. P. Moncada, L. H. Penning, L. C. Timm, D. Gabriels, and W. M. Cornelis, "Visual examinations and soil physical and hydraulic properties for assessing soil structural quality of soils with contrasting textures and land uses," Soil and Tillage Research, vol. 140, pp. 20-28, 2014.

[25] P. B. Tinker, J. S. I. Ingram, and S. Struwe, "Effects of slashand-burn agriculture and deforestation on climate change," Agriculture, Ecosystems \& Environment, vol. 58, no. 1, pp. 13-22, 1996.

[26] S. M. Nandwa, "Soil organic carbon (SOC) management for sustainable productivity of cropping and agro-forestry systems in Eastern and Southern Africa," Managing Organic Matter in Tropical Soils: Scope and Limitations, Springer, Berlin, Germany, pp. 143-158, 2001.

[27] C. Baum and F. Makeschin, "Effects of nitrogen and phosphorus fertilization on mycorrhizal formation of two poplar clones (Populus trichocarpa and P. tremula x tremuloides)," Journal of Plant Nutrition and Soil Science, vol. 163, no. 5, pp. 491-497, 2000.

[28] F. Oehl, E. Frossard, A. Fliessbach, D. Dubois, and A. Oberson, "Basal organic phosphorus mineralization in soils under different farming systems," Soil Biology and Biochemistry, vol. 36, no. 4, pp. 667-675, 2004.

[29] Y.-z. Cao, X.-d. Wang, X.-y. Lu, Y. Yan, and J.-h. Fan, "Soil organic carbon and nutrients along an alpine grassland transect across Northern Tibet," Journal of Mountain Science, vol. 10, no. 4, pp. 564-573, 2013.

[30] D. F. Cusack, W. L. Silver, M. S. Torn, and W. H. McDowell, "Effects of nitrogen additions on above-and belowground carbon dynamics in two tropical forests," Biogeochemistry, vol. 104, no. 1-3, pp. 203-225, 2011. 